\title{
Use of cyanoacrylate in the coaptation of edges of surgical wounds
} Aplicação do cianoacrilato na coaptação das bordas de feridas cirúrgicas

\author{
Ruthinéia Diógenes Alves Uchôa Lins ${ }^{1}$ \\ Kátia Simone Alves dos Santos ${ }^{1}$ \\ Renata Torres Moreira da Silva ${ }^{2}$
}

\author{
Raquel Christina Barboza Gomes ${ }^{1}$ \\ Paula Vanessa da Silva ${ }^{2}$ \\ Ianny Alves Ramos ${ }^{3}$
}

\begin{abstract}
Cyanoacrylate has been used in several fields of different surgical specialties as an adhesive for closure of gingival flaps and in mucous and cutaneous lacerations. One of its advantages is that it has an excellent immunological response. In view of aesthetic needs, cyanoacrylate has been applied with satisfactory results, when compared with sutures. It presents better coaptation of edges of cutaneous and mucosal lesions, smaller residual scars, and biocompatibility. However, it is limited to areas of little tissue tension. This work attempts to provide a literature review with the aim of revealing the advantages of using tissue adhesives, especially cyanoacrylates, in wound coaptation in comparison with conventional methods.
\end{abstract}

Keywords: Cyanoacrylates; Sutures; Wound healing

Resumo: O cianoacrilato tem sido utilizado em diversos campos das especialidades cirúrgicas como adesivo no fechamento de retalhos gengivais e em lacerações mucosas e cutâneas, além de apresentar uma ótima resposta imunológica. Tendo em vista as necessidades estéticas, o cianoacrilato tem sido aplicado com resultados satisfatórios quando comparado aos fios de sutura, pois apresenta melhor capacidade de coaptação das bordas de uma lesão de pele e mucosa, menor cicatriz residual e biocompatiblidade, estando limitado, entretanto, a zonas de baixa tensão tecidual. Frente a tais considerações, o presente trabalho busca desenvolver uma revisão literária, objetivando revelar as vantagens do uso dos adesivos teciduais, especialmente os cianoacrilatos, na coaptação de feridas, em detrimento da utilização dos métodos convencionais com fios de sutura.

Palavras-chave: Cianoacrilatos; Cicatrização; Suturas

\section{INTRODUCTION}

Suturing is an important stage in surgery, since it favors and accelerates recuperation of the incised tissue. In order to correctly indicate the type of suture to be performed, the professional should worry about pre, trans, and postoperative aspects so that effective regeneration of the injured tissue is promoted. For instance, the professional should indicate and choose the best way to perform coaptation of the injured tissue to facilitate healing. ${ }^{1}$
According to Silveira and Heitz (1998), sutures cause tissue irritation, leading to an inflammatory response of low intensity and short duration. However, they are soft, flexible, basically inelastic, resistant to traction and torsion, easy-to-sterilize, low-cost, and have thin and regular caliber. ${ }^{2}$

With the emergence of chemical tissue adhesives and due to the interference of sutures in the process of tissue healing and to the difficulty of suturing

Received on 08.08.2011.

Approved by the Advisory Board and accepted for publication on 05.03.2012

* Work conducted at the Department of Odontology, Paraiba State University (Universidade Estadual da Paraiba - UEPB) - Campina Grande (PB), Brazil. Financial Support: None Conflict of Interest: None 
children, some professionals started replacing the conventional suture with chemical substances called tissue adhesives, especially cyanoacrylates, used for synthesis of surgical wounds. ${ }^{3-7}$ The chemical adhesive is also used in children for being an easy-to-perform, quick, and painless method that leaves small scars, except for when there are complications. ${ }^{8}$

Chemical adhesives have unique properties, including the following: bacteriostatic effect; hemostatic effect; biodegradation; biocompatibility, except for the methyl-cyanoacrylate; and easy manipulation. However, they also show some inconvenient characteristics, such as less resistance to tension and toxicity in some patients. ${ }^{10,11,12}$ One of their multiple advantages is that, compared to sutures, cyanoacrylates reduce surgical time in tissue synthesis. ${ }^{5,13}$

In Brazil, especially in the area of odontology, ethyl cyanoacrylate - a low-cost and clinically well-evaluated chemical adhesive - has been used as adhesive material in the closure of gingival flaps, in mucous and cutaneous lacerations, as well in pulp capping. ${ }^{14}$ According to Bruns et al. (1998) and Gomes (2000), ethyl cyanoacrylate facilitates the patient's life, since the patient does not need to return to the clinic for suture removal. ${ }^{13,15}$

This study aims at carrying out a literary review on the viability of using cyanoacrylate to close the edges of surgical wounds, emphasizing its advantages and disadvantages when compared to conventional sutures.

\section{LITERATURE REVIEW}

There are several current research papers showing that the use of chemical adhesives to close the edges of surgical wounds in moist and living tissue represents a viable alternative to reach such purpose. . $^{12,13,16}$

Chemical adhesives were discovered and synthesized by Ardis in 1949. They were first used in human beings in 1959, when their adhesive properties were finally reported by Coover. ${ }^{17,18}$ Since then, they have been widely studied as to their capacity to facilitate the synthesis of wound edges, reduce surgical time, minimize patient discomfort, and avoid new visits to the clinic for suture removal. ${ }^{19}$

Initially, the authors investigated many different structural forms of chemical adhesives based on cyanoacrylates, from methyl, ethyl, n-propyl, n-amyl, nhexyl, among others, to the most effective formula, which is octyl cyanoacrylate. ${ }^{10,12,20-23}$

In 1966, Bhaskar et al. (1967) showed that the cyanoacrylate $(\mathrm{CH} 2=\mathrm{C}(\mathrm{CN})-\mathrm{COOR})$ chemical adhesive adheres to moist tissue, presents hemostatic properties, and is phagocytized by histiocytes. ${ }^{12}$ The authors carried out tests with several types of cyanoacry- lates, such as ethyl cyanoacrylate, methyl cyanoacrylate, propyl cyanoacrylate, isobutyl cyanoacrylate, and butyl cyanoacrylate, with the last one showing better clinical results, followed by ethyl cyanoacrylate. Kline and Hayes (1963) observed, in their experiment, that methyl cyanoacrylate is the one that presents the highest degree of histotoxicity, causing edema and tissue necrosis, and thus not being indicated for clinical use. ${ }^{24}$ On the other hand, ethyl cyanoacrylate adhesives do not promote inflammatory reaction, in spite of showing faster degradation; therefore, they are clinically indicated for wound closure. $25,26,27$

Lascaz Netto and Macedo (1986) conducted some research with human beings in order to clinically evaluate healing of five free gingival grafts fixed with a chemical adhesive. ${ }^{28}$ Such authors concluded that the results found were satisfactory, especially when it came to reducing surgical time, since the adhesive was placed without any difficulty and showed fast polymerization, regardless of the presence of saliva or bleeding. Also, the authors observed that tissue repair occurred normally, without any untoward events.

Santos et al. (1990) carried out a histopathological study on tissue repair in wounds produced in the back of rats and compared suture with the application of the ethyl cyanoacrylate tissue adhesive. ${ }^{3}$ Two incisions were performed in the back of 24 rats, one was sutured and the other was submitted to application of ethyl cyanoacrylate. The incisions were analyzed one, three, five, and seven days after the surgery. The authors verified that the adhesive showed to be less aggressive than the suture in the initial stage of the repair process; however, in the final stages of tissue repair, they tended to show similar results.

Barreiro, Servin and Diaz (1995) conducted a study with human beings using the ethyl cyanoacrylate adhesive in the coaptation of edges of incised cutaneous tissue in curved and suprapubic surgical wounds. ${ }^{26}$ The conventional internal suture was performed, and the adhesive was placed on the superficial portion. The authors observed no intolerance to the adhesive or dehiscence of the edges and, therefore, concluded that the method is easy to apply, economical and present no side effects.

In order to obtain better effectiveness, chemical adhesives should be used within 72 hours after exposure to air. The time needed for their polymerization is approximately 55 seconds, varying according to the surface to which they will be applied, such as endothelium, mucous membrane, skin, blood, and bone. Because of their liquid form, chemical adhesives have the ability to penetrate irregular surfaces of the tissue, promoting strong adhesion. ${ }^{29.31}$ However, their bacterial toxicity is, in part, determined by products generated from degradation of polymers and formation of double bonds of 
monomers combined with free amino acids and/or hydroxyl groups that are common in bacterial cell walls. ${ }^{32}$

The histotoxicity of the tissue adhesive is attributed to the polymerization of the polymer that generates two subproducts: formaldehyde and cyanoacetate (toxic). Its degradation varies according to the size of the carbon chain of the cyanoacetate ester; the bigger the carbon chain, the slower the degradation of this substance. ${ }^{15}$

Marques (1997), seeking to improve and optimize tissue synthesis after exodontia, conducted an experimental study with rats using the ethyl cyanoacrylate tissue chemical adhesive to repair the gingival mucosa. ${ }^{33}$ The results obtained through a histomorphological analysis showed that ethyl cyanoacrylate allows more uniform tissue proliferation in the initial healing stage, without causing any damage to the final stages of tissue repair.

Bruns et al. (1998) carried out an experiment with 83 children that sought help at the Emergency Department of the Thompson Children's Hospital from February to June of 1996 with the objective of evaluating the efficacy of the 2-octyl cyanoacrylate chemical adhesive in dilacerations. ${ }^{13}$ They did not only use the adhesive, but also the conventional method with non-reabsorbable suture. The amount of time needed for synthesis of the dilacerations with both the adhesive and suture was recorded, and it was observed that surgical time was reduced in the proportion of 2.9 minutes with the use of 2-octyl cyanoacrylate. The time needed when suture was used was 5.8 minutes. Pain was also evaluated by parents based on their children's reports, and it was found that the group that used 2-octyl cyanoacrylate presented such manifestation with less intensity. Considering the results, the authors concluded that 2-octyl cyanoacrylate is a pretty acceptable alternative, when compared to conventional suture methods.

In 1998, Toriumi, Ogrady and Ddesai observed 111 patients that were submitted to elective surgical procedures performed by the same surgeon. The patients to use the 2-octyl cyanoacrylate adhesive and the conventional suture for closure of the edges of surgical wounds were randomly selected. It was observed that the time needed to close the surgical wound with the use of suture was three minutes and forty-seven seconds, being approximately four times longer than the time needed for closure with 2-octyl cyanoacrylate, which lasted about fifty-five seconds. ${ }^{16}$ The surgical wounds were evaluated five to seven days after the surgical procedure to check for the presence of infection, wound dehiscence, or tissue reaction to a foreign body. The wounds closed with suture showed an aspect of intense inflammatory process and erythematous areas around the incision, whereas the incisions closed with the adhesive showed no tissue reaction. Both groups did not show dehiscence, hematoma, or presence of infection. Ninety days after the closure of the wounds, a satisfactory aesthetic result was observed, with no significant differences between the two groups.

When evaluating the sterility of cyanoacrylate and its biocidal activity in relation to microorganisms, Ueda et al. (2004) verified that cyanoacrylate is a safe alternative as to its sterility. However, it does not show any bacteriostatic and/or bactericidal effect in relation to $S$. mutans, S. xylosis and P. aeruginosa, which indicates the necessity of maintaining an antibiotic therapy in case of infection. ${ }^{34}$

Gomes (2000), in an investigation involving human beings, used ethyl cyanoacrylate in the coaptation of the edges of surgical wounds resulting from excisional biopsies, with a maximum length of 20 millimeters, to evaluate the viability of using tissue adhesives in wound closure. ${ }^{15}$ In this experiment, 15 patients with lesions that did not suggest malignancy were selected. Those lesions were located on the skin and in the head and neck regions. Removal of the lesions and tissue synthesis with the chosen tissue adhesive were performed. When the surgical wounds were examined, it was observed that the edges of the wounds were coapted seven days later in $86.7 \%$ of the cases and 28 days later in $93.3 \%$ of the cases. Thus, it was concluded that the use of the tissue adhesive did not interfere in the healing process and that its application in the coaptation of the edges of surgical wounds is viable, since no contraindications were observed.

Oliveira and Cruz et al. (2000) carried out a study to evaluate the efficacy of the 2-octyl cyanoacrylate adhesive in comparison with the conventional suture technique in the fixation of total skin grafts, analyzing their integration. ${ }^{35}$ The authors verified that the average time of fixation with the adhesive was 23 seconds compared to four minutes when suture was used. Therefore, better integration and less time for graft fixation were demonstrated with the use of 2octyl cyanoacrylate.

According to Elosua et al. (2001), little malleability, the possibility of injuring the mucosa and skin, the low coefficient of friction, and the instability of the suture knot give the suture material significant disadvantages when it comes to coaptation of edges of facial wounds, which demand a less apparent scar and, therefore, a better healing process. ${ }^{36}$

Tissue adhesives show satisfactory aesthetic and healing results in odontology, especially in the area of oral and maxillofacial surgery. However, cyanoacrylates are the least indicated for closure of highly mobile areas such as joints; areas of friction, like feet and 
hands; and those areas where precise alignment is a priority, like eyelids and face. Its use is basically restricted to simple dilacerations in areas of low tension and easy access. It is especially recommended for children, to avoid the fear of sutures and their removal afterwards. ${ }^{37}$

In 2005, Santana et al. conducted a comparative study on the use of an adhesive implant based on cyanoacrylate and the use of silk suture in subcutaneous tissue of rats. ${ }^{38}$ In this experiment, 20 rats had their backs incised and were then submitted to adhesive implants and silk suture. The animals were sacrificed two, five, ten and twenty days after surgery, with the areas adjacent to the implants being removed and submitted to microscopic analysis. The researchers concluded that alpha-cyanoacrylate, when necessary, may replace the silk suture, since it showed better results than the silk suture regarding tissue reaction at the subcutaneous connective tissue level.

In 2009, Saska et al. carried out an investigation to analyze the compatibility between the ethyl-cyanoacrylate adhesive and the butyl-cyanoacrylate adhesive and to compare the repair of incisions in the back of rats using these adhesives and suture. ${ }^{39}$ Two surgical holes were prepared in the back of 15 rats. A tube of polyethylene was implanted in each hole and filled with the chosen adhesive. Ethyl cyanoacrylate was placed in the hole on the right and butyl cyanoacrylate was placed in the one on the left. Between the two incisions coapted with the adhesives, a medium-size incision was performed, which was closed with silk suture. The animals were sacrificed seven, thirty-five, and a hundred and twenty days after surgery. The authors concluded that both adhesives allow similar healing of the incised tissue and, therefore, may replace the silk suture in closure of wounds, lacerations, or cutaneous incisions, reducing the duration of the surgical procedure.

\section{DISCUSSION}

Andrade and Montenegro (1992), Edwab (1995), and Laney and Tolman (1990) agree that the selection of the suture material requires an evaluation of the time during which the material should be maintained to promote closure of the wound and also of the tension needed during this time. ${ }^{40-42}$ Moreover, according to these authors, the biocompatibility of this material is defined by the intensity of the acute inflammatory process, initially triggered by the lesion induced by a transfixion needle and by the presence of an antibody-antigen response, as well as by the delay in scar fibroblast proliferation, which will result in isolation of the body.

Pereira et al. (2005) showed, in their experiment, that the cyanoacrylate chemical adhesive adhe- res to moist tissue, decreases the duration of the surgery, minimizes patient discomfort, and avoids a new visit to the clinic to remove the sutures. Their work corroborates the reports by Azevedo, Marques and Bombana (2003). ${ }^{19,20}$

The histomorphological studies conducted by Dutra (1991) and Saito et al. (2002), in which they used ethyl cyanoacrylate, found that tissue healing in the initial stages was satisfactory. ${ }^{4,43}$ Dutra (1991) concluded his experiment recommending the use of the adhesive only in epithelial tissue and warned that its use in connective tissue should be avoided. ${ }^{4}$ On the other hand, Saito et al. (2002) suggested the use of the adhesive in both the epithelial and connective tissue. ${ }^{43}$

According to Ferreira et al. (2004), Perron et al. (2000), and Toriumi et al. (1998), tissue adhesives show satisfactory aesthetic and healing results in odontology, especially in the area of oral and maxillofacial surgery. ${ }^{14,16,44}$ However, according to Cardoso et al. (2004), cyanoacrylates should not often be indicated for healing of highly mobile areas such as joints, areas of friction, and areas where precise alignment is a priority. These authors defend that their use should be restricted to children and cases of simple dilacerations. ${ }^{37}$

In accordance with Toriumi et al. (1998) and Santos et al. (2003), the inflammatory response caused by 2-octyl-cyanoacrylate is light, that is, inferior to that caused by conventional sutures, which makes it more advantageous regarding tissue repair. ${ }^{16,7}$

When conventional sutures are compared with 2-octyl-cyanoacrylate, it is observed that the latter offers superior cosmetics results, since this material is biodegradable and bacteriostatic and has great adhesive potential, in addition to presenting other advantages such as hemostasis promotion and maintenance of the position of the injured tissue. These observations are corroborated by Bhaskar et al. (1966), Santos et al. (2003), Santana et al. (2004) and Toriumi et al. (1998). ${ }^{7,12,16,38}$ Ferreira et al. (2004) also state that its use is pretty advantageous, especially in children, since it is not necessary to anaesthetize the injured region and it does not involve suture removal in the postoperative phase. ${ }^{14}$ However, according to reports by Baptista (1999), in spite of the multiple advantages of tissue adhesives over conventional sutures, some surgeons are still afraid of using 2-octyl-cyanoacrylate due to its histotoxicity and difficult application. ${ }^{32}$

According to Pereira et al. (2005), the time needed to close the epidermis with sutures is three or four times longer than the time needed when using 2-octylcyanoacrylate. ${ }^{20}$ Regarding tissue protection against infections, according to Toriumi et al. (1998), 2-octylcyanoacrylate offers better results than conventional 
sutures in the first five to seven days; however, over time, within at most 90 days, the results are similar. ${ }^{16}$

More recently, Saska et al. (2009) found results similar to those of other researchers that used ethyl cyanoacrylate as well as butyl cyanoacrylate in bone tissue and in the back of animals, proving that chemical adhesives are biocompatible with the analyzed structures. ${ }^{3,28,29,31,39,45-48}$

According to Souza et al. (2007), who investigated the biocompatibility of ethyl cyanoacrylate in the closure of rat skin compared to octyl cyanoacrylate and suture, the use of ethyl cyanoacrylate showed several advantages in relation to the other two. It showed good tolerance, not inducing necrosis, allergic reactions, or infections. ${ }^{47}$ On the other hand, Toriumi et al. (1990) showed that ethyl cyanoacrylate causes more inflammation than butyl cyanoacrylate. ${ }^{48}$

There are several studies comparing chemical adhesives and conventional sutures. These studies evaluate differences regarding healing capacity, bactericidal and bacteriostatic properties, clinical and histological aspects, presence of postoperative pain, intensity of local reaction, and hemostatic actions. All of the studies mentioned in this paper, especially those developed by Bhaskar et al. (1966), Lehman et al. (1966), Matsumoto et al. (1967), Gottlob et al. (1967),
Frisch and Bhaskar (1969), and Saito et al. (2002), obtained conclusive results according to which chemical adhesives may be an additional and effective option for coaptation of surgical wound edges. $10,11,12,21,22,43$

\section{FINAL REMARKS}

Cyanoacrylates seem to present a great advantage as adhesives for the skin and mucosa. They are indicated for a variety of surgical procedures, such as closure of gingival flaps, closure of mucous and cutaneous lacerations, and endodontic surgeries, with bigger biocompatibility and small secondary tissue reaction than conventional sutures;

Other advantages of using cyanoacrylates, especially with regard to children, are the fact that anesthesia is not necessary and that there is no removal of sutures;

The use of cyanoacrylates is restricted to simple dilacerations in areas of no or low tension and of easy access, which constitutes one of its disadvantages;

Additional studies on making these products easier to apply and more accessible should be conducted, aiming at increasing the use of 2-octyl-cyanoacrylate in surgical specialties, especially in areas where aesthetics demands are high. 


\section{REFERENCES}

1. Caldas Jr AF, Gusmão ES. Estudo clínico comparativo da coaptação dos tecidos gengivais, após cirurgia a retalho, utilizando-se etil-cianoacrilato (super-bonder) e fio de sutura. Rev Period. 1998;7:354-2.

2. Silveira JOL, Beltrão GC. Exodontia. Porto Alegre: Missau; 1998. Capítulo 8, Instrumental, materiais, equipamentos e ambiente cirúrgico; p. 89-117.

3. Santos GM, Lacaz Netto R, Santos LM, Okamoto T, Rocha RF. Uso do Super Bonder no reparo das feridas cirúrgicas. RG0. 1990;38:435-39.

4. Dutra, CR. Contribuição ao estudo histofisiológico da reparação tecidual mediante 0 uso de dois adesivos derivados do cianoacrilato comparativamente à sutura com fio de algodão em dorso de rato [dissertação]. São Paulo (SP): Universidade de São Paulo; 1991. 80 p.

5. Quinn J, Maw J, Ramotar K, Wenckebach G, Wells G. Octylcyanoacrylato tissue adhesive versus suture wound repair in a contamined modei. Surgery. 1997;122:69-72.

6. Noordzij JP, Foresman PA, Rodeheaver GT, Quinn JV, Edlich RF. Tissue adhesive wound repair revisited. J Emerg Med. 1994;12:645-9.

7. Santos RL dos, Gusmao ES, Caldas Junior A de F, Silveira RCJ. Uso do etil-cianoacrilato e Prime \& Bond 2.1 em dente hipersensíveis pós-terapia periodontal. Rev Bras Odontol. 2003:60:27-29.

8. Mattick A. Use of tissue adhesives in the management of pediatric lacerations Emerg Med J. 2002;19:382-5.

9. Saska S, Rossi ET, Conte Neto N, Souza SF, Gabrielli MAC, Hochuli-Vieira Adesivos de cianoacrilato para fixação de xenoenxertos. Rev Cir Traumatol BucoMaxilo-Fac. 2009;9:93-102

10. Matsumoto T, Hardaway RM 3rd, Heisterkamp CA 3rd, Pani KC, Leonard F Margetis PM. Cyanoacrylate adhesive and hemostasis. Arch Surg. 1967;94:858-60.

11. Gottlob R, Blümel $G$. The toxic action of alkyl cyanoacrylate adhesive on vesseis: comparative studies. J Surg Res. 1967;7:362-7.

12. Bhaskar SN, Frisch J, Cutright DE, Margetis P. Effect of butylcyanoacrylate on the healing of extration wounds. Oral Surg Oral Med Oral Pathol. 1967;24:604-16.

13. Bruns TB, Robinson BS, Smith RJ, Kile DL, Davis TP, Sullivan KM, et al. A new tissue adhesive for laceration repair in children. J Pediatr. 1998:132:1067-70.

14. Ferreira OS, Dourado M, Perrone C. Uso de adesivo de n-butilcianoacrilato para imobilização de retalho posicionado coronalmente - estudo clínico controlado. Braz Oral Res. 2004;8:87

15. Gomes RBC. Avaliação clínica da utilização do etilcianoacrilato (SuperBonder R) em biópsias excisionais [dissertação]. João Pessoa (PB): Universidade Federal da Paraíba; 2000. 68 p.

16. Toriumi DM, O'Grady K, Desai D, Bagal A. Use of octyl-2-cyanoacrylate for skin closure in facial plastic surgery. Plast Reconstr Surg. 1998;102:2209-19.

17. Ardis AE. U.S. Patents No. 2467926 and 2467927 (1949)

18. Coover HW, Joyner FB, Shearer Jr NH, Wicker Jr TH. Chemistry and performance of cyanoacrylate adhesive. J Soc Plast Eng. 1959;15:413-7.

19. Azevedo CL, Marques MM, Bombana AC. Efeitos citotóxicos de cianoacrilatos usados como material de obturação retrógrada: uma análise in vitro. Pesqui Odontol Bras. 2003;17:113-8.

20. Pereira AC, Pereira PPI, Souza JM, Fernandes PA, Ferreira SM, Duarte DP. Análise microscópica de dois métodos de coaptação de fendas cirúrgicas: sutura e adesivo químico. Braz. Oral Res. 2004;18(Supplement - Proceedings of the 21nd Annual SBPq0 Meeting):242.

21. Lehman RA, Hayes GJ, Leonard F. Toxicity of alkyl-2-cyanoacrylate. I. Periphera nerve. Arch Surg. 1966;93:441-6.

22. Frisch J, Bhaskar SN. Free mucosal graft with tissue adhesives: report of 17 cases. J Periodontol. 1968:39:190-5.

23. Forrest J0. The use of cyanoacrylates in periodontoal surgery. J Periodontol. 1974:45:225-9

24. Kline DG, Hayes GJ. An experimental evaluation of the effect of a plastic adhesive, methyl-2-cyanoacrylate, on neural tissue. J Neurosurg. 1963;20:647-54.

25. Diaz Barreiro PG, Servin Ramirez JE, Diaz Lopez DE. Experiencia en 10 casos de sutura cutânea usando el adhesivo etilcianoacrilato. Ginecol Obstet Méx. 1995 63:10-4

26. Al-belasy FA, Amer Mz. Hemostatic effect of n-butyl-2-cyanoacrylate (histoacryl) glue in warfarin-treated patients undergoing oral surgery. J Oral Maxillofac Surg. 2003:61:1405-9.

27. Saska S, Roslindo EB, Bolini PDA, Minarelli-Gaspar AM. Uso do adesivo à base de etil-cianoacrilato na reparação óssea. Rev Bras Ortop. 2004;39:461-7.
28. Lascaz Neto R, Macedo ML. Estudo clínico da reparação de enxerto livre da gengiva fixado por um adesivo à base de cianoacrilato. Rev Assoc Paul Gir Dent. 1986;40:164-70.

29. Giray CB, Sungur A, Atasever A, Araz K. Comparasion of silk sutures and n-butyl2-cyanoacrylate on the healing of skin wounds. A pilot study. Aust Dent J. 1995;40:43-5.

30. Weber SC, Chapman MW. Adhesives in orthopedic surgery a review of the literature and in vitro bonding strengths of bone-bonding agents. Clin Orthop Relat Res. 1984;191:249-56.

31. Shermak MA, Wong L, Inoue W, Crain BJ, Im MJ, Chao EY, et al. Fixation of the craniofacial skeleton with butyl-2-cyanoacrylate and its effect on histotoxicity and healing. Plast Reconstr Surg. 1998;102:309-18.

32. Baptista RRC. Los cianoacrilatos en cirurgía. Rev Sanid Milit Mex. 1995;49:55-8.

33. Marques ESB. Influência do etilcianoacrilato na reparação do epitélio da mucosa gengival e do alvéolo dental após exodontia: estudo histomorfológico em ratos [tese]. Araçatuba (SP): Universidade Estadual Paulista; 1997. 69 p.

34. Ueda EL, Hofling-Lima AL, Sousa LB, Tongu MS, Yu MCZ, Lima AAS. Avaliação de um cianoacrilato quanto à esterelidade e atividade biocida. Arq Bras Oftalmol. 2004:67:397-400.

35. Oliveira E Cruz GA, Freitas RS, Fillus Neto J, Tolazzi ARD, Groth AK, Biondo-Simões MLP. Avaliação da integração de enxerto de pele com a utilização do 2-octilcianoacrilato: estudo experimental em ratos. Acta Cir Bras. 2000; 15(Supl.3):58-60.

36. Elosua JI, López GS, Bové GM, Mata De, Martinez GJ. Supuesta alergia al Nylon tras cirugía de la catarata. Arch Soc Esp Oftalmol. 2001;4:263-6.

37. Cardoso CAC, Arisawa EAL, Costa SBN, Ribeiro TP, Silva CMOM. Estudo histomorfométrico da reparação de lesões cirúrgicas na mucosa oral de ratos - associação de sutura, adesivos e laserterapia. Braz. Oral Res. 2004;8(Suppl):241.

38. Santana AF, Silva UH, Torres BCA, Santiago LM. Estudo comparativo entre o poliglatina 910 e etilcianoacrilato em dorso de ratos: avaliação clínica e histopatológica. Braz Oral Res. 2004;8(Suppl):46.

39. Saska S, Gaspar AMM, Hochuli-Viera R. Adesivos à base de cianoacrilato para síntese de tecido mole. An Bras Dermatol. 2009;84:585-92.

40. Andrade Z, Montenegro MR. Patologia: processos gerais. 3 ed. São Paulo: Ateneu; 1992.

41. Edwab RR. Choosing suture materials and needles. Dent Econ. 1995;85:78-9

42. Laney WR, Tolman DE, editors. Tissue integration in oral, orthopedic and maxilofiacial reconstruction. Vol. 1.Illinois: Quintessence books; 1992. p.218-226.

43. Saito $\mathrm{CTMH}$, Okamoto T, Arenega A. Implante adesivo a base de cianoacrilato e fio de seda em tecido subcutâneo de ratos - Estudo microscópico. BCI. 2002:9:134-8.

44. Perron AD, Garcia JA, Parker Hays E, Schafermeyer R. The efficacy of cyanocrylate - derived surgical adhesives for use in the repair of lacerations during competitive athletics. Am J Emerg Med. 2000;18:261-3.

45. Caroli A, Marcuzzi A, Limontini S, Maiorana A. An experimental study of a cyanoacrylate biological adhesive in view of its use in the fixation of various fractures of the fingers. Ann Chir Main Memb Super. 1997;16:138-45.

46. Gonzalez E, Orta J, Niemshik L, Galera R, Onay R, Rojas 0. Ethyl-2-cyanoacrylate fixation of the cranial bone flap after craniotomy. Surg Neurol. 2000;53:288-9.

47. Souza SC, Oliveira WL, Soares DFOS, Briglia CH, Athanázio PA, Cerqueira MD, et al. Comparative study of suture and cyanoacrylates in skin closure of rats. Acta Cir Bras. 2007:22:309-16.

48. Toriumi DM, Raslan WF, Friedman M, Tardy ME. Histotoxicity of cyanoacrylate tissue adhesives: acomparative study. Arch Otolaryngol Head Neck. Surg. 1990;116:546-50.

How to cite this article: Lins RDAU, Gomes RCB, Santos KSM, Silva PV, Silva RTM, Ramos IA. Use of cyanoacrylate in the coaptation of edges of surgical wounds. An Bras Dermatol. 2012;87(6):871-6. 